REVISTA ANDALUZA DE ANTROPOLOGÍA.

NÚMERO 9: LA REPRESENTACIÓN DE LAS CULTURAS EN LA MUSEOLOGÍA ANTROPOLÓGICA DEL ESTADO ESPAÑOL

SEPTIEMBRE DE 2015

ISSN 2174-6796

[pp. 158-186]

http://dx.doi.org/10.12795/RAA.2015.i09.07

Recibido: 25/03/2015

Aceptado: 14/06/2015

\title{
PATRIMONIO E IDENTIDAD. REPRESENTACIONES DE LA CULTURA REGIONAL EN LOS MUSEOS ETNOGRÁFICOS DE EXTREMADURA
}

\author{
Juan M. Valadés Sierra
}

Museo de Cáceres

\section{Resumen.}

La representación de la identidad regional extremeña, discutida y de afirmación relativamente reciente, en los museos etnográficos se caracteriza primeramente por la ausencia de una referencia comprensiva de toda la comunidad. En su lugar, varias son las experiencias de museos etnográficos deámbito local, comarcal o provincial cuyos orígenes se sitúan en el primer tercio del siglo XX. A partir de ahí, es preciso destacar los casos de la sección etnográfica del Museo de Cáceres y de los museos de Olivenza y Plasencia como referentes regionales del modelo de museo etnográfico vigente hasta finales del siglo pasado. Frente a ello, la primera década de la centuria actual trajo consigo la creación de un buen número de nuevos museos locales centrados en la presentación de procesos productivos, sociales o rituales que responden a un nuevo concepto museográfico en que gana terreno la interpretación del Patrimonio con un escaso número de objetos y un especial protagonismo de las nuevas tecnologías. El presente trabajo trata de analizar el funcionamiento de ese modelo dual en la región así como sus luces y sombras en el momento actual y de cara a un futuro inmediato. 


\title{
Palabras clave.
}

Museos etnográficos, diacronía, Cáceres, Olivenza, Plasencia, museo local, museo de proceso, museografía tradicional, museografía sin objetos, participación comunitaria.

\section{HERITAGE AND IDENTITY. REPRESENTATIONS OF REGIONAL CULTURE IN ETHNOGRAPHIC MUSEUMS OF EXTREMADURA}

\begin{abstract}
.
The representation of the regional identity of Extremadura, discussed and relatively recent claimed, in Ethnographic Museums is firstly characterized by the absence of a comprehensive reference to the whole community. Instead, there are some experiences of local, regional or provincial Ethnographic Museums whose origins are in the first third of the 20th century. From there, it should be noted the cases of the Ethnographic Section of the Cáceres Museum, and also Olivenza and Plasencia Museums as regional references of the model of Ethnographic Museum used until the end of last century. On the other hand, the first decade of the present century led the creation of many new local museums focused on the presentation of productive, social or ritual processes, which respond to a new museum concept where the interpretation of Heritage is gaining importance by using a small number of objects and the special relevance of new technologies. This paper analyzes the performance of this dual model in the region and its lights and shadows nowadays and facing the near future.
\end{abstract}

\section{Keywords.}

Ethnographic museums, diachrony, Caceres, Olivenza, Plasencia, local museum, museum of process, traditional museography, museography without objects, community participation.

\section{INTRODUCCIÓN: ¿CULTURA REGIONAL EXTREMEÑA?}

Fuera de los límites de la región, parece generalizada la línea de pensamiento que niega a Extremadura una personalidad regional claramente definida, atribuyéndole caracteres mixtos y prestados de Andalucía en el sur y castellanoleoneses en el norte; el mismo Caro Baroja define la región, en su devenir histórico desde el periodo medieval, como "avanzada de Andalucía por un lado y de León por otro" (1976: II, 121), interpretando una frecuente opinión de que la región extremeña, a falta de una personalidad propia, es el resultado de las influencias castellanas y leonesas en la provincia de Cáceres y de una 
afinidad andaluza en la de Badajoz, salvándose tal vez la mesopotamia ubicada entre el Tajo y el Guadiana como expresión genuina de una cierta personalidad extremeña no contaminada por sus vecinos de norte y sur (Marcos, 1998: 3). Esa idea se relaciona con un territorio que carece de fronteras netas, a no ser en su borde septentrional, donde se separan la altiplanicie de la submeseta del Duero y la cuenca del Tajo, y con su papel histórico de invernadero para las cabañas ganaderas castellanas; el espacio extremeño se organiza en torno a los ejes de sus comunicaciones, el que corre de norte a sur, la llamada "Vía de la Plata" por la que discurrían personas y ganados desde antes de la época romana, y los longitudinales que coinciden con el curso de los ríos Tajo y Guadiana (Barrientos, 1990). A partir de ahí, la región ha funcionado en la Historia con un alto grado de aislamiento, articulándose hacia adentro de sus "salidas" hacia Salamanca y Sevilla, Lisboa y Madrid; Plasencia, Cáceres, Mérida, Almendralejo y Zafra conforman los hitos del eje norte-sur mientras que los tres ejes transversales se apoyan en Plasencia, Coria y Navalmoral de la Mata, Cáceres, Valencia de Alcántara y Trujillo y Mérida, Badajoz, Don Benito y Villanueva de la Serena. Un territorio tan amplio y con un grado de aislamiento tal, al que debe añadirse la división en dos provincias, y en el que existe una gran diferencia entre las comarcas serranas del norte minifundista y las dehesas y planicies de la Serena y la Campiña sur, ha generado un alto grado de comarcalización que dificulta la conformación de un único discurso geográfico e histórico, y por tanto museográfico, de alcance regional.

Pese a ello, y a lo que comúnmente se cree, históricamente ha habido una conciencia regional extremeña que no le ha sido reconocida a la Comunidad desde fuera hasta tiempos recientes; con la fundación de la Real Audiencia de Extremadura (1790), el estado borbónico escucha la vieja demanda de las ciudades extremeñas y reconoce de iure a la región no sólo como una entidad administrativa y territorial, sino también implícitamente como una realidad con personalidad geográfica y étnica diferenciada (Marcos, 1995a: 135), algo que, por otro lado, era desde antiguo una realidad fáctica ampliamente conocida; ya desde finales del siglo XV Extremadura es reconocida como un ente distinguible de Castilla y de Andalucía, como se evidencia en obras como el Libro de Grandezas de España de Pedro de Medina (1548) y en otras producidas ya desde la región, entre las que destaca la Descripción e Historia General de la Provincia de Extremadura de Fray Francisco de Coria (1606), que reivindica no sólo la existencia de la entonces provincia con personalidad propia, sino también la empresa americana como base y fundamento de la extremeñidad (Palacios, 1988: 22).

Se viene admitiendo que la división provincial del Reino en 1822, certificada once años más tarde por el proyecto de Javier de Burgos, ha sido una importante rémora para la formación de una conciencia regional extremeña. La creación de las dos provincias en 
torno a las capitales de Cáceres y Badajoz generó un progresivo extrañamiento entre los dos territorios y una constante pugna no exenta de cainismo que continúa vigente en gran medida (Flores, 1988: 38). Sin duda estas discusiones provincianas restaron energías a la creación de un verdadero proyecto regional, pero desde al menos la segunda mitad del siglo XIX se pueden rastrear iniciativas y movimientos que reivindican la existencia de Extremadura como comunidad diferenciada y que ponen las bases para la formación de una conciencia regional fundamentada en la necesidad de superar el estado de postración en que se encontraba y ponerla al mismo nivel que el resto de territorios españoles. Pensadores como Julián Antero de Zugasti (1862), Juan Luis Cordero (1917) o Antonio Elviro Berdeguer con su manifiesto Extremadura para los extremeños en 1920 (Sánchez Marroyo, 1998) defendieron firmemente la necesidad de resolver el "problema agrario", mientras un movimiento regionalista de corte romántico se inspiraba en la historia y la literatura regionales como expresión del alma extremeña para las propuestas autonomistas hechas al gobierno en 1919 y 1924, y ya en época republicana se registra la primera propuesta de estatuto de autonomía promovida en julio de 1931 por un grupo de personajes moderados entre los que destaca José López Prudencio (Sánchez González, 1997: 33-43).

Tras la guerra civil, y durante el largo paréntesis franquista, la conciencia regional se despierta de nuevo vinculada al drama de la emigración, otro efecto de la desigual distribución de la riqueza. Se toma conciencia de que Extremadura está siendo expoliada de sus riquezas naturales, que producen sus plusvalías fuera de la región, y al final de la dictadura Extremadura se une al generalizado movimiento autonomista que surge en todo el país (Naredo, 1978: 107); realmente, es en el último cuarto del siglo XX cuando se forja, impulsada por los nuevos poderes públicos regionales, la conciencia de ser y pertenecer a una entidad regional diferenciada, con una personalidad propia y distinta de otras comunidades españolas. Progresivamente, la afirmación de la identidad regional fue normalizándose, y si todavía en 1988 se organizaban foros de discusión sobre el alcance de tal identidad (VV.AA., 1988), el sentimiento ha ido calando en las nuevas generaciones y hoy la personalidad regional de Extremadura ha dejado de ser tema de discusión para convertirse más bien en objeto de estudio (Calvo, 1996; Marcos, 1998).

\section{APROXIMACIÓN A LA MUSEOGRAFÍA ETNOGRÁFICA EN EXTREMADURA}

La aparición del referente etnográfico en los museos extremeños es relativamente temprana, pues hay que remontarse a la tercera década del siglo pasado para rastrear esos orígenes. Como es bien conocido, en 1925 se organizó en Madrid la Exposición del Traje Regional, una gran muestra nacional que reunía indumentaria de todo el país y se organizaba por regiones; su director técnico, el antropólogo Luis de Hoyos 
Sainz, se inspiró en los museos nórdicos de finales del siglo anterior para presentar la indumentaria mediante la recreación de ambientes, como el interior de viviendas, calles, tiendas o talleres, utilizando maniquíes de tamaño natural y contextualizando así su uso privado y público. El comité colaborador con el que Hoyos contó en Extremadura para seleccionar los modelos que habían de representar a la región estuvo integrado por estudiosos y artistas como el pintor Adelardo Covarsí Yustas (1885-1951); éste conoció obviamente la presentación final de los trajes en la exposición madrileña y trató de reproducir el modelo museográfico cuando, cuatro años después, fue designado secretario de la comisión organizadora por la provincia de Badajoz del Pabellón de Extremadura en la Exposición Iberoamericana de Sevilla. Así, en la ciudad hispalense la representación extremeña tuvo como principal atractivo una "cocina folklórica" perfectamente equipada con su gran chimenea, cacharros de cobre y loza, perolas, sartenes, y diecisiete maniquíes ataviados con trajes típicos de distintos pueblos de la región de acuerdo con las pautas dadas por Covarsí y llevadas a la práctica por el secretario del comité de la provincia de Cáceres, Miguel Ángel Orti Belmonte (18911973), que además coordinó la compra de los trajes altoextremeños, y por el también cacereño Ángel Rubio Muñoz-Bocanegra (1901-1962), delegado en Sevilla del comité conjunto extremeño y responsable inmediato del montaje (Valadés, 2013: 1.848-1.858). Al finalizar la exposición iberoamericana, en 1930, los materiales expuestos que habían sido adquiridos ad hoc, caso de los maniquíes con sus trajes y los accesorios de la cocina, fueron repartidos entre los dos comités provinciales que habían sido constituidos por las respectivas Diputaciones; dado que Orti Belmonte, secretario del comité cacereño era, al mismo tiempo y desde 1921, director del Museo de Cáceres, el cual entonces ocupaba en precario unas salas del Instituto de Enseñanza Media, solicitó y obtuvo la donación de todo ese material para el museo, que sólo un año después iniciaba una nueva instalación en la llamada Casa de las Veletas. Así, cuando finalmente se inauguró el Museo en su sede propia el 12 de febrero de 1933, Orti dispuso las llamadas "salas folklóricas" en el subsuelo del palacio, por las que era preciso pasar para acceder al aljibe andalusí que desde la inauguración es el mayor atractivo de la institución. En estas salas reconstruyó una cocina con los once maniquíes correspondientes a la provincia de Cáceres, ataviados con los trajes de Montehermoso, Malpartida de Plasencia, Torrejoncillo, Cáceres, Casar de Cáceres, y Malpartida de Cáceres, y con sus enseres, procedentes todos ellos de la cocina folklórica del pabellón extremeño en Sevilla, materiales a los que añadió varias piezas de loza, cacharros para la preparación de alimentos y elementos de iluminación que fueron donados por las alumnas que Orti tenía en la Escuela Normal, de la que era asimismo catedrático (Valadés, 2008: 30). 


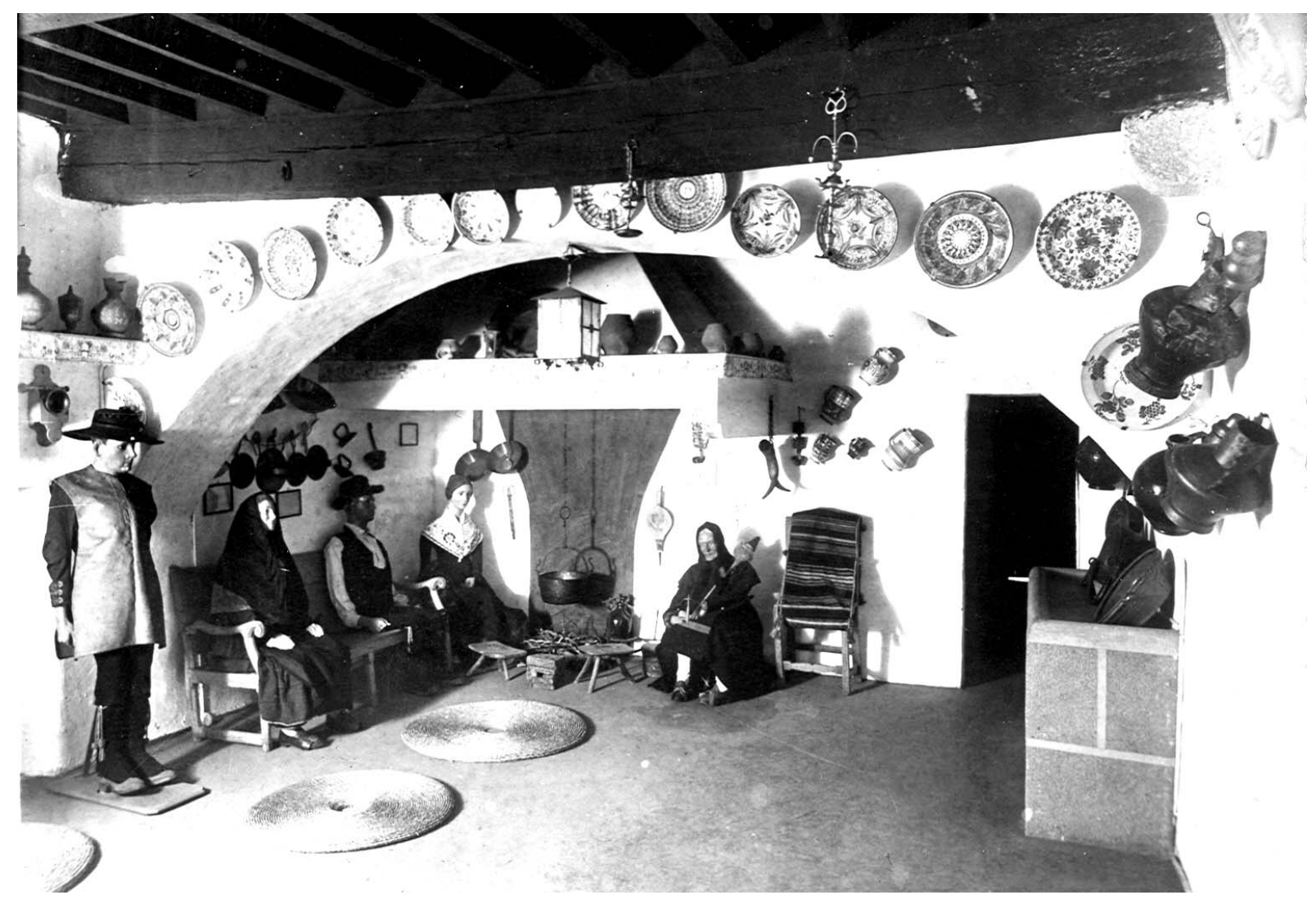

Foto 1. Cocina folklórica del Museo de Cáceres (1933) (Archivo fotográfico del Museo de Cáceres)

Con todo ello se formó la primera experiencia museográfica de contenido etnográfico que se conoce en Extremadura; estas salas, que constituyen el embrión de la Sección de Etnografía del Museo de Cáceres, se mantuvieron abiertas al público con tales contenidos hasta 1972, siendo conocidas por varias generaciones de cacereños y estudiadas por investigadores como Ruth Matilda Anderson (1951: 218) durante su estancia en la ciudad en el año 1949, un ejemplo más de cómo una gran exposición, la Iberoamericana de 1929, tiene entre otras consecuencias la creación de nuevos museos (Sánchez Gómez, 2013: 160), o como en este caso, de una sección nueva e inédita en la región en un museo que, por lo demás, tenía un marcado contenido arqueológico y artístico.

Habrá que esperar más de cuarenta años para poder mencionar otro aporte a la museografía etnográfica en Extremadura, y también se produce en el Museo de Cáceres, durante el proceso de remodelación de la sede principal del mismo, la Casa de las Veletas; entre 1972 y 1976 las salas folklóricas son desmontadas y en su lugar se incorpora a la nueva instalación toda una sección etnográfica que pasa a ocupar seis salas y una galería de la planta alta del edificio (Beltrán, 2008: 92); el nuevo despliegue de material etnográfico se hace posible gracias a la adquisición, por el Estado y por la Diputación Provincial, de dos colecciones sucesivas de objetos que había formado el comerciante placentino Pedro 
Pérez Enciso, en las que destacan piezas textiles de indumentaria y de la casa, loza y una multitud de objetos metálicos o de madera de distintos tipos. Lamentablemente, y como suele suceder en estos casos, el lote de piezas fue reunido sin ningún criterio científico ni sistemático, salvo el gusto del coleccionista, y también fue dispuesto en la exposición permanente sin un criterio antropológico coherente, sino que se ordenó por materiales constitutivos; así, una sala se dedicaba a industrias textiles, otra presentaba piezas de metalistería, cerámica, vidrio, madera, asta y hueso, y el resto recogía piezas de lino e indumentaria, mientras la galería se dedicaba al ajuar casero (González Mena, 1976: 389394); desapareció el viejo montaje de la recreación de ambientes y en su lugar las piezas pasaron a presentarse en el interior de vitrinas acompañadas de escuetas explicaciones, dibujos y fotografías.

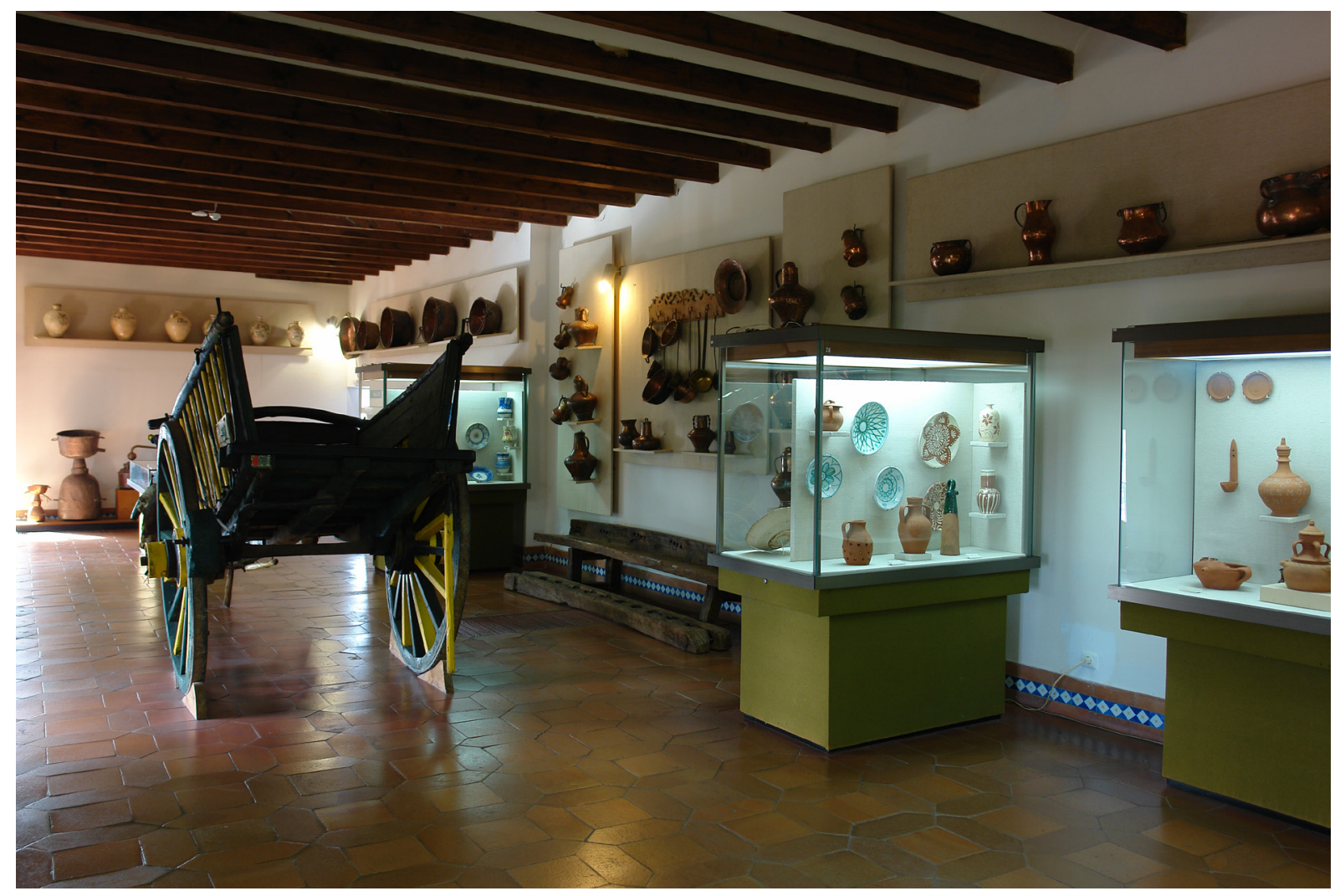

Foto 2. Sección de Etnografía del Museo de Cáceres (1998) (Archivo fotográfico del Museo de Cáceres)

Con todo, la sección de Etnografía del Museo de Cáceres ha sido un referente en la región, como veremos, al igual que su catálogo, editado en 1976; todavía hoy permanece con escasas variaciones el contenido de una de aquellas seis salas, pendiente de una remodelación tan necesaria como reiteradamente pospuesta por el Ministerio de Cultura.

En 1980, con motivo de la IV Semana de Extremadura en la Escuela, se expuso temporalmente una parte de la colección etnográfica reunida en Olivenza por Francisco 
González Santana, y dos años después se abrió ya como museo municipal. En paralelo, el ayuntamiento oliventino rehabilitó el edificio de la antigua cárcel del partido judicial y en 1991 se inauguraba el nuevo museo ocupando su sede, tras la cesión de toda la colección (Limpo, 2005: 106). El Museo de Olivenza nació con carácter local y a partir de la obra de un coleccionista, al igual que sucedía en Cáceres, pero la amplitud de miras de éste, y las continuas donaciones de particulares de toda la región, fueron determinándolo progresivamente a adquirir un contenido y una denominación, tal vez excesiva, de "Museo Etnográfico Extremeño"; aunque realmente no es representativo de toda la Comunidad Autónoma, sí hay que decir que su contenido sobrepasa el ámbito meramente local. Por otro lado, en Olivenza se llevó a la práctica una museografía distinta de la que ofrecía la sección etnográfica de Cáceres desde 1976; especialmente en el montaje inaugurado en 1991 que se ha mantenido hasta el presente, se volvió a la recreación de ambientes optando por la reconstrucción de talleres, tiendas, estancias domésticas o escuelas, con lo que se mejora la contextualización del patrimonio material expuesto, aunque al precio de perder la información identificativa y textual que debe asociarse a las piezas.

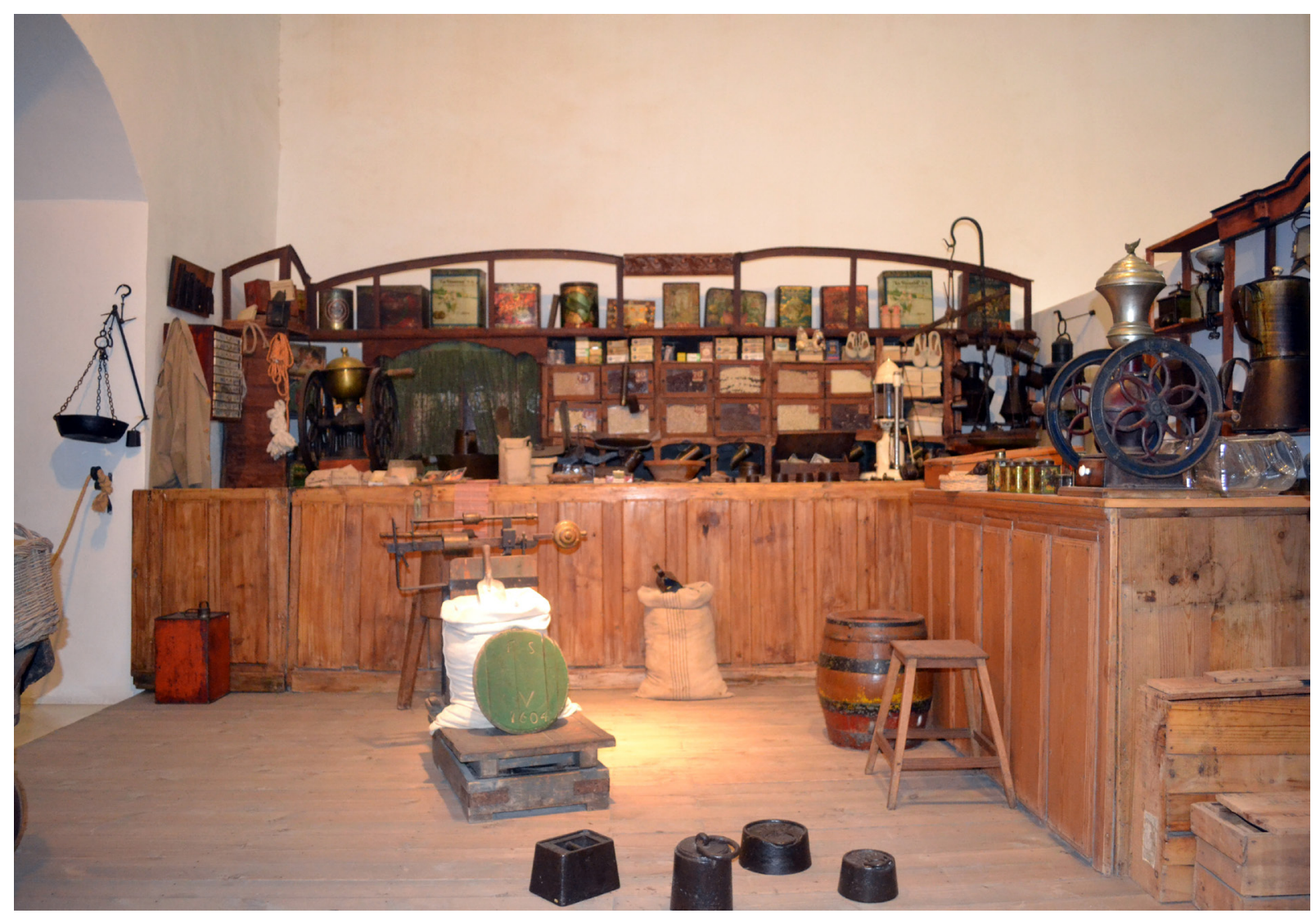

Foto 3. Museo Etnográfico Extremeño de Olivenza (Archivo fotográfico del Museo de Olivenza)

Si la provincia de Badajoz ya contaba con un museo etnográfico en la década de los ochenta, la de Cáceres no iba a ser menos; a partir de 1983 la Institución Cultural "El Brocense" de la Diputación Provincial cacereña comenzó a reunir una amplia colección etnográfica destinada a la creación de un Museo de Artes y Costumbres Populares 
que nunca llegó a ver la luz como tal. Paralelamente, el mismo organismo provincial promovió una exposición itinerante por varios pueblos de la provincia que se tituló "Muestra Etnográfica Cacereña", formada por cientos de objetos que habían sido prestados principalmente por particulares (González Mena, 1986). Las piezas reunidas para el frustrado museo terminaron depositadas en el Museo de Cáceres, formando parte de su actual colección etnográfica, pero la Diputación llegó efectivamente a crear una institución de esta naturaleza en 1989, con el Museo Etnográfico Textil "Pérez Enciso" de Plasencia, una apuesta descentralizadora de la política museística que ubicaba en la capital del Jerte una institución forjada a partir de una nueva colección adquirida al citado coleccionista D. Pérez Enciso. En este caso, la museografía fue encomendada a la que será primera directora del centro, Aurora Martín Nájera, quien, auxiliada por Ma Ángeles González Mena, Andrés Carretero Pérez y María Pía Timón Tiemblo, concibe una museografía que ayude a mostrar procesos culturales de creación o transformación de recursos, si bien se prefirió alojar en vitrinas gran parte de las piezas textiles expuestas y en conjunto el resultado quedó ciertamente mediatizado por el proyecto arquitectónico (Martín Nájera, 2005: 86).

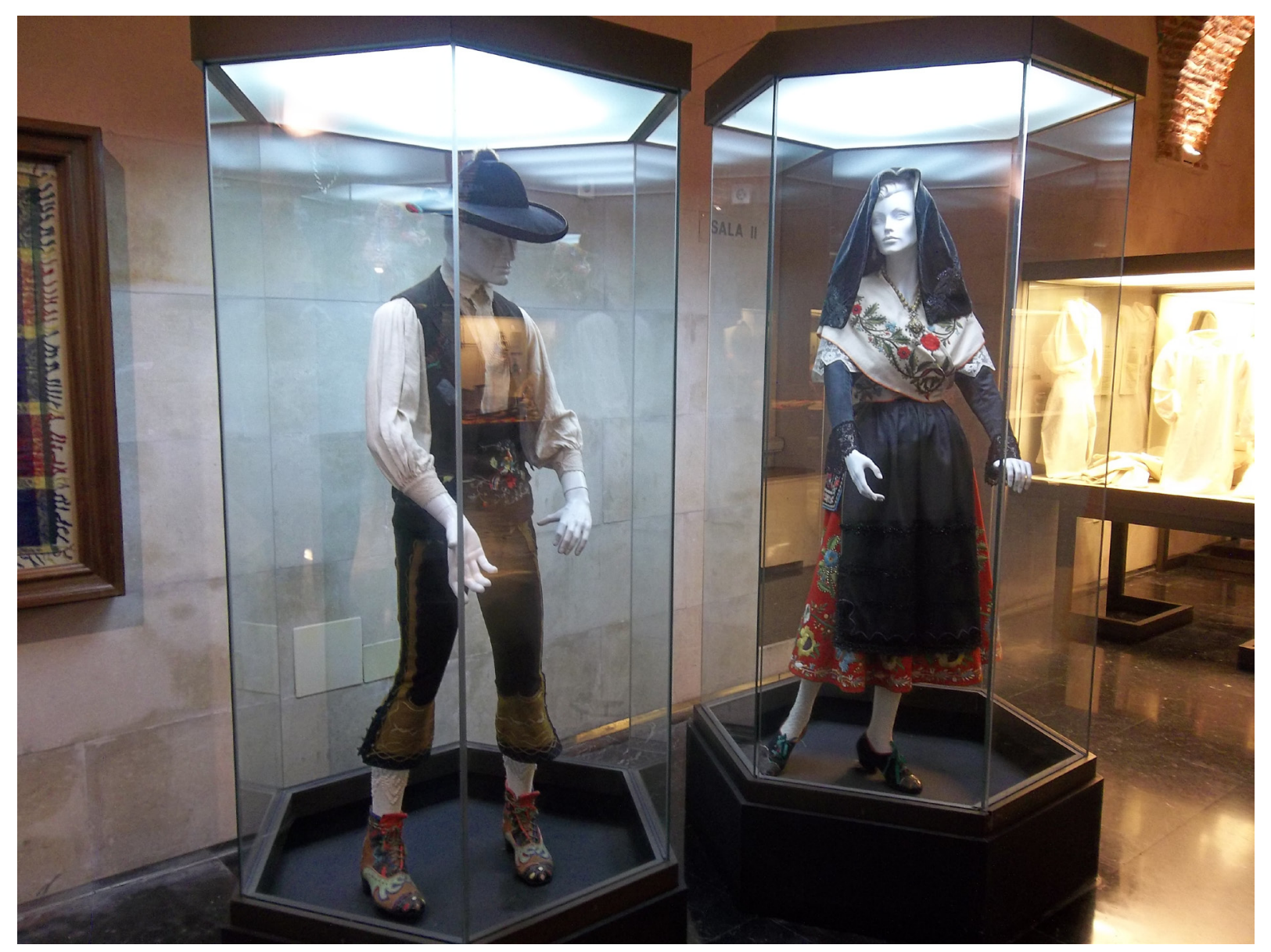

Foto 4. Museo Etnográfico Textil Pérez Enciso de Plasencia 
Tras la apertura del Museo de Plasencia, y con los crecientes recursos que, procedentes de los fondos europeos, comenzaron a llegar a los municipios de la región, se experimenta una primera oleada de proyectos de creación de museos etnográficos locales de impulso municipal que ya hemos analizado con anterioridad (Valadés, 2010: 1.078-1.079); algunos de esos proyectos llegan a hacerse realidad en la década de los noventa, caso de los museos de Puebla de Alcocer (Badajoz), abierto en 1992, Cilleros (Cáceres) en 1995 o Serradilla (Cáceres) en 1996. Ya para entonces, y desde 1987, había comenzado su andadura un curioso museo etnográfico ubicado en una pequeña pedanía de Trujillo, Huerta de Ánimas, de iniciativa completamente privada e impulsado por el párroco del lugar, D. José Blanco. Estos museos se nutren de las donaciones o cesiones de piezas hechas por los vecinos, y raramente cuentan con asesoramiento profesional para el acopio de materiales, montaje, inventario o almacenaje; una excepción en este sentido sería el de Cilleros, un museo impulsado por una asociación cultural cuyo proyecto fue asumido por las autoridades locales y en cuya gestación participó la antropóloga Ingrid Kuschick; el de Puebla de Alcocer, por su parte, incluye entre las piezas expuestas algunas que pertenecieron o son recuerdo del célebre "gigante extremeño" que vendió en vida su cuerpo al doctor González Velasco y cuyo esqueleto puede contemplarse en el Museo Nacional de Antropología de Madrid. Por su parte, el Museo de Huerta de Ánimas plantea un recorrido por los distintos ambientes laborales y domésticos de la "vida tradicional" al estilo de los museos nórdicos al aire libre, dotado de varias edificaciones que conforman un pequeño "pueblo" levantado con participación directa de la comunidad local. En cuanto al de Serradilla, se trata de un museo creado e impulsado por los vecinos del pueblo con el apoyo del ayuntamiento; formado con piezas donadas por los particulares, desde 2012 desapareció como tal para integrarse la colección, muy reducida en su exposición, en el nuevo Centro de Interpretación de la Huella del Hombre en Monfragüe.

Sin embargo, el hecho más destacable en esta época es la formación de una considerable colección destinada a la creación del Museo Etnográfico de Azuaga y la comarca de la Campiña Sur, comenzada en 1984 y encomendada a un profesional de la Antropología, como es Javier Marcos Arévalo bajo los auspicios del ayuntamiento azuagueño. La ingente colección fue, en este caso sí, recogida de una manera sistemática y respondiendo a un programa establecido, documentándose detalladamente con un especial interés por la contextualización de las piezas a fin de que en su momento sirvieran para presentar procesos sociales y culturales. Lamentablemente, el proyecto de museo tardaría veinte años en cuajar, y cuando finalmente se inauguró en 2004, ya sin la dirección de Marcos, el resultado tenía muy poco que ver con el proyecto iniciado, quedando la exposición permanente reducida considerablemente por los condicionamientos del edificio, un antiguo cine; por otro lado, y según parece, la colección reunida se ha visto considerablemente mermada en estos años por la retirada de numerosas piezas. 
En 1996 la Junta de Extremadura publica un Decreto por el que crea la Red de Museos autonómica, y tres años después promulga la nueva Ley del Patrimonio Histórico y Cultural que consagra la existencia de dicha red. El marco legal dispuesto y su ulterior desarrollo administrativo tenía entre otras finalidades la de organizar de algún modo un auténtico brote de museos etnográficos creados o proyectados, sin ninguna planificación ni control, a lo largo y ancho de la región durante esos años. En 1995, Javier Marcos Arévalo (1995b: 171) enumeraba un total de veintiocho proyectos en marcha en diferentes pueblos y ciudades, de los que menos de media docena han llegado a plasmarse en la realidad; con anterioridad hemos definido la creación de la red de museos como un intento de dar coherencia y sentido a semejante sarpullido museológico (Valadés, 2010a: 175-176), creando para ello una categoría legal, la exposición museográfica permanente, que daría cabida a todos esos proyectos surgidos de la iniciativa municipal o comarcal y que vendría a caracterizarse por la carencia de personal cualificado y especializado y por la renuncia de facto al papel de dinamizador social a que aspiran los museos locales imbricados en los intereses de la comunidad. Estos museos, "de segunda categoría" en cuanto a sus colecciones, programa de actividades y recursos humanos fueron bautizados por la Consejería de Cultura como "museos de identidad", huyendo de la típica conformación de los museos etnográficos al uso para centrar el discurso en la presentación de procesos productivos, comerciales o rituales que son o han sido importantes en las localidades o comarcas elegidas en tiempos más o menos recientes. Tratándose de una insistente demanda de los municipios, el gobierno regional se hizo cargo de la rehabilitación de los inmuebles, en su mayoría edificios más o menos antiguos y emblemáticos de cada localidad que en gran medida han sido salvados para este fin, y de la instalación museográfica, mientras que los ayuntamientos habían de disponer el personal y los medios para su funcionamiento; no obstante, la supervivencia de estos pequeños centros sigue dependiendo de los aportes anuales de la Junta de Extremadura que se materializan mediante convenios de colaboración. Esta solución deparó a los usuarios de los museos extremeños, y durante años, la paradójica sorpresa de visitar en esos centros de segundo orden unas instalaciones museográficas avanzadas y dotadas de unos recursos tecnológicos y expositivos de los que carecían -y siguen careciendo- los dos grandes e históricos museos estatales de gestión transferida a la Junta de Extremadura.

La gran mayoría de los mal llamados "museos de identidad" creados por la administración regional en esta fase son etnográficos de contenido y vocación, y varios de ellos se han puesto en funcionamiento en realidad para reconducir, hacia ese concepto de museo como testigo y memoria de la comunidad, algunos de los anteriores proyectos de museos etnográficos surgidos de la simple idea de presentar una colección de objetos donados o cedidos por la gente del pueblo. Los más importantes de este grupo son el Museo de la Alfarería de Salvatierra de los Barros (2001-2003), el Museo del Granito de Quintana de la Serena (2002), el Museo de los Auroros en Zarza Capilla (2004), el ya mencionado 
Etnográfico de Azuaga, el Museo del Empalao de Valverde de la Vera (2005), el Museo del Queso en Casar de Cáceres (2005), el Museo del Turrón de Castuera (2005), el Museo del Aceite de Monterrubio de la Serena (2006), el Museo de la Cereza de Cabezuela del Valle (2007), el Museo del Pimentón de Jaraíz de la Vera (2007), el Museo del Carnaval de Badajoz (2007), el Museo del Corcho de San Vicente de Alcántara (2008) y el Museo de las Ciencias del Vino de Almendralejo (2009).

Estos pequeños museos aspiraban a exponer, potenciar y favorecer la reflexión, desde una perspectiva antropológica, sobre los rasgos culturales, sociales y económicos más destacados de los territorios en que se ubican (Caldera y Tercero, 2008: 34). Aparecidos en una década que puede calificarse sin ninguna duda de expansiva en cuanto a presupuestos y creación de infraestructuras culturales, los centros resisten de manera desigual la nueva situación de recortes sobre recortes que se vive en este ámbito desde 2010; así, la mayoría de ellos consiguen abrir de martes a domingo, aunque los de Azuaga y del Empalao sólo abren los fines de semana, mientras que el de los Auroros únicamente se puede visitar concertándolo previamente $y$, cuando se redactan estas líneas, están "temporalmente" cerrados los del Turrón de Castuera y el Aceite de Monterrubio.

Otro museo etnográfico que debe citarse, aunque no formó parte de ese impulso inaugurador de la Junta de Extremadura, es el Etnográfico de Don Benito, abierto al público en 2000 siguiendo el modelo del museo oliventino de la recreación de ambientes, a partir de donaciones y cesiones de piezas por particulares, aunque en este caso utilizando un bello edificio ejemplo de la arquitectura doméstica aristocrática del siglo XIX. El museo tiene una historia cambiante en la que ha tenido mucha importancia la disponibilidad de fondos europeos con que durante años se financió parte de su funcionamiento; desde que en 2012 esos fondos desaparecieron o se redujeron, se suprimió la figura del/la Director/a, con lo que la institución perdió su categoría legal de Museo, algo que también ha sucedido a museos de otras temáticas como el arqueológico de la Cárcel Real de Coria, hoy reducido a Exposición Museográfica Permanente fuera de la Red de Museos de Extremadura.

Y por último es preciso mencionar varios centros de interpretación de contenidos etnográficos repartidos por la región, como el de la Octava del Corpus de Peñalsordo, creado en 2001 en la misma dinámica que los llamados museos de identidad, el de la Arquitectura Popular en Burguillos del Cerro y el de la Minería en Cáceres, ambos de 2003 y financiados por el proyecto Alba Plata de revitalización y puesta en valor de la Vía de la Plata en Extremadura, el del Pozo de las Nieves en Villar del Rey (2010) o el del Carnaval de Ánimas de Villar del Pedroso (2013), impulsado por la Diputación Provincial de Cáceres. 


\section{LA AUSENCIA DE LA REGIÓN. LA AUSENCIA DE LAS PROVINCIAS Y OTRAS AUSENCIAS}

Como ya habrá reparado el lector, hasta el momento no hemos mencionado un museo etnográfico de la región, que trate de abarcar y representar el Patrimonio cultural de toda la Comunidad Autónoma extremeña. Tal museo no existe; de hecho, ni siquiera existe un museo etnográfico para cada provincia, y no porque no haya sido reclamado en reiteradas ocasiones desde el ámbito científico (Marcos, 1992).

A decir verdad, la inexistencia de un museo regional de contenido etnográfico es una muestra más de la escasa articulación histórica de las dos provincias como una verdadera región; no existe un museo etnográfico regional como no existe un museo de Bellas Artes de la región ni un museo histórico o arqueológico que contribuya a sustentar el corpus ideológico y simbólico de todo el territorio extremeño. A falta de tal museo etnográfico, importante referencia en este sentido sigue siendo un museo local que, como el de Olivenza, se presenta en su denominación como "Museo Etnográfico Extremeño" a pesar de radicarse, y presentar un buen número de piezas originarias precisamente de una de las localidades "menos extremeñas de Extremadura", si se tiene en cuenta que no fue incorporada al territorio regional hasta 1801. Así mismo, el Etnográfico Textil de Plasencia a duras penas puede representar a la provincia cacereña si se tiene en cuenta que la mayor parte de sus objetos procede del tercio norte de la Alta Extremadura además de tener una marcada dedicación a la materia textil.

En efecto, tampoco cada una de las provincias cuenta propiamente con un museo etnográfico que represente eficazmente su territorio. Sólo se cuenta, en este sentido, con la Sección de Etnografía del Museo de Cáceres, tan necesitada como está de una actualización en su discurso y su museografía; pero al menos se trata de una presentación amplia que abarca la práctica totalidad del espacio provincial. Sin embargo, la ciudad de Badajoz cuenta con dos museos provinciales, uno de Arqueología y el otro de Bellas Artes, pero carece de museo etnográfico provincial, y ya hemos señalado que difícilmente puede Olivenza representar a la provincia; acaso el de Don Benito pudiera asumir esa función si no hubiera sido despojado de una dirección profesional para quedar convertido en poco más que un extraordinario almacén visitable.

Ante esa ausencia de la región y de las provincias, encontramos un panorama de la museología etnográfica en Extremadura en que predomina lo local, bien por impulso de las comunidades que dotan de pequeños museos a sus pueblos con o sin el apoyo municipal, casos de Cedillo, Logrosán, Montehermoso, Garrovillas de Alconétar, etc. o bien por la iniciativa del gobierno regional a través del ya mencionado proyecto de "museos de identidad". Ese predominio de lo local se sustenta en un discurso variado, 
pero coincidente en ofrecer una versión del patrimonio cultural en la que no hay sitio para la diacronía, donde se diseña un presente etnográfico atemporal y en el que también están ausentes los matices; la sociedad carece de minorías, no existen los gitanos ni los esclavos, y los moriscos y judíos sólo aparecen en lugares de dedicación monográfica como el Centro de Interpretación de Hornachos o la supuesta sinagoga de Valencia de Alcántara, que además al parecer no fue tal (Hervás, 2014: 278).

Pero el capítulo de ausencias no se cierra aquí, pues comprobamos que tampoco existe en los museos el hecho más importante y decisivo de la historia de Extremadura en el siglo $\mathrm{XX}$, como es la emigración masiva experimentada desde el ámbito rural a las ciudades españolas y europeas, la cual arrebató a la región cerca de la mitad de su población en tan solo quince años. Hay que buscar en el universo virtual para encontrar esa justa referencia a los extremeños que tuvieron que marcharse en busca de un mundo mejor; se trata del Museo Virtual de la Emigración Extremeña (Muveex) creado en 2011 por la Junta de Extremadura y apenas mantenido en estos años en la dirección www.muveex.

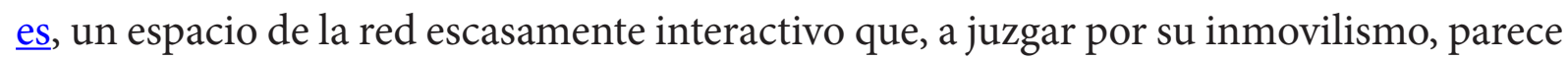
haber dejado de interesar a la administración autonómica.

Otra triste realidad de los museos etnográficos extremeños es la ausencia de antropólogos en sus plantillas, salvo alguna rara y honrosa excepción. Y, si es preciso reconocer que los dos licenciados en Antropología Social integrados en la plantilla de la Dirección General de Patrimonio Cultural de la Junta de Extremadura participaron activamente en los proyectos de creación de varios de los "museos de identidad", no es menos cierto que una vez inaugurados, éstos han venido funcionando con más voluntarismo que profesionalidad y sin el apoyo técnico de la Consejería, especialmente desde que en 2010 fue suprimido el puesto de Director/a de la Red de Museos de Extremadura, pues entonces desapareció su único vínculo con la ciencia antropológica y la Museología como disciplina y como profesión. A decir verdad, la tónica general en la aplastante mayoría de las instituciones que la publicidad vende como "museos" en Extremadura es la falta de personal cualificado, entendiendo por ello titulados superiores ejerciendo su profesión con contratos laborales más o menos estables como responsables de los centros; de hecho, especialmente los centros de interpretación y un buen número de los mal llamados "museos de identidad" funcionan con ordenanzas, auxiliares de museos o guías por todo personal.

\section{4. ¿DIFERENTES CONCEPTOS DE MUSEO O DOS ÉPOCAS DISTINTAS?}

Como ya ha quedado apuntado, y se viene subrayando en la bibliografía crítica, una de las aportaciones de los nuevos museos etnográficos extremeños creados bajo la hégira del gobierno regional es la renovación de la museografía, resumida en la desaparición 
o drástica reducción de vitrinas utilizadas para la exposición de los materiales y en el predominio de las recreaciones de ambientes como mejor forma de presentar los bienes culturales como si estuvieran en su contexto de creación y uso. De hecho, se ha querido trazar un paralelismo causal entre estas dos maneras de concebir las salas de un museo y otras tantas visiones del papel de los museos en la sociedad; a un museo inmovilista y escasamente renovado en el plano teórico y práctico se asocia la vieja presentación de las piezas descontextualizadas y aisladas del público en sus vitrinas, mientras que la recreación de ambientes, la colocación de los objetos en sus lugares aproximados de uso, la eliminación de barreras entre piezas y usuarios del museo, o incluso la desaparición de las piezas para ser sustituidas por información gráfica, textual o en distintos soportes audiovisuales, parece unida al nuevo concepto de museos como "expresiones culturales de enorme interés para el conocimiento de la diversidad cultural" (Delgado, 2012: 46) o como centros de dinamización social y cultural y atracción turística.

Ese razonamiento no deja de ser cierto, en parte; es claro que la nueva museología ha dado lugar, por todo el mundo, a museos más participativos, donde se fomenta la interacción del público, no sólo en las salas con respecto a la exposición, sino en otros aspectos fundamentales de la institución, que incluyen su funcionamiento y gestión. Sin embargo, ya hemos señalado que, en la museografía etnográfica, la recreación de ambientes no es novedosa con respecto al uso predominante de vitrinas, tampoco en Extremadura; creemos que la renovación conceptual del museo como institución debe, y de hecho suele, ir acompañada de una vocación preferente por la explicación participativa de procesos culturales, en la que los objetos son realmente vehículos de significado que ayudan a entender tales procesos; en este sentido la cuestión no es si los objetos están dentro de vitrinas o están al alcance del público, sino más bien si realmente están ahí porque sirven para explicar estructuras, procesos o rasgos culturales o simplemente por unas cualidades estéticas o materiales que los hacen excepcionales y por tanto consideramos que deben custodiarse y protegerse mediante una barrera separadora de la "realidad cotidiana" del visitante.

La paradoja mayor es que aquellos museos, no sólo etnográficos, que cuentan con profesionales preparados y decididos para transformar su inmediata realidad haciendo de las instituciones depósito de la memoria colectiva, reflejo de la diversidad cultural y herramientas para el desarrollo sostenible, son los que cuentan con los montajes museográficos más antiguos y obsoletos y también, pese a ser los más importantes y visitados de la región, aquellos que cuentan con menos recursos financieros para su actualización acorde con la renovación teórica de los postulados que manejan. Así, museos como el de Cáceres exhiben un montaje originado hace cuarenta años, mientras el Arqueológico de Badajoz y el Etnográfico de Plasencia montaron sus salas hace ya más de un cuarto de siglo. Por ello, acusar de inmovilismo a quien se halla imposibilitado de 
moverse no deja de ser una broma de mal gusto.

En definitiva, cabe plantearse si esa dicotomía entre distintos conceptos de museo a través de sus montajes, conservador el museo basado en vitrinas que custodian las piezas "sagradas" a las que rinde culto el turista en su peregrinaje cultural, avanzado y dinámico el pequeño museo local dotado de los últimos avances museográficos y de un discurso más flexible y actual, no responde más bien a las dos épocas, bien distintas, en que se originaron cada uno de esos montajes. Estamos convencidos de que la oferta museográfica sería mucho más homogénea y actualizada, en general, si los presupuestos públicos se hubiesen gastado de una manera más equitativa entre todos los museos en vez de haber "echado el resto" durante años en esos pequeños museos, tan necesarios entonces para acallar a las comunidades locales ansiosas de tenerlos, como prescindibles ahora para unas administraciones que no desean ni pueden seguir manteniéndolos pero tampoco se atreven a cerrarlos.

Hechas estas reflexiones, a la hora de repasar lo que muestran los museos de interés antropológico en nuestra comunidad rápidamente se comprueba que, grosso modo, pueden establecerse dos grandes grupos entre ellos; por una parte tenemos los museos que siguen y repiten el formato del conocido museo etnográfico, una versión reducida, local y localista del museo "de artes y costumbres populares" que apareció en diferentes capitales españolas en los años sesenta y setenta del siglo pasado, en los que por otro lado la identidad regional se da por supuesta y no precisa explicación, y por la otra aquellos que responden al modelo de "museos de proceso" que tratan de presentar rasgos peculiares y distintivos de la comunidad, donde tal vez por ello la identidad regional desaparece para ser sustituida por la localidad o la comarca como referencias culturales principales.

\section{EL VIEJO FORMATO “MUSEO ETNOGRÁFICO”}

En nuestro país, y salvo escasas excepciones, no existe una tradición de museos al aire libre al estilo escandinavo; en su lugar, el modelo que se impuso desde mediados del siglo XX fue el del museo etnográfico o de artes y costumbres populares, a menudo instalado en un inmueble histórico o significativo desde el punto de vista de la arquitectura vernácula, e inspirado más o menos lejanamente en museos etnográficos como los de Bilbao (1919), Museu d'Arts i Costums Populars de Barcelona (1942), sección etnológica de Mallorca (1961), Cantabria (1966), Sevilla (1972), etc. El Museo de Cáceres, con la reapertura de su Sección de Etnografía en 1976 fue en cierta manera una referencia regional para este modelo, al igual que los museos de Olivenza y Plasencia; estos centros acostumbran a presentar a lo largo de sus salas unos contenidos generalistas que se refieren a la agricultura y la ganadería, el comercio, la indumentaria, los oficios, el transporte, la educación formal, la estratificación social, la vida cotidiana en el hogar y otros, invariablemente enmarcados en un pasado sin fechas concretas que se refiere siempre a etapas anteriores al gran éxodo 
rural extremeño desde finales de los años cincuenta del siglo pasado. En otras palabras, tratan de presentar una visión de conjunto de la "sociedad tradicional" basada principal o exclusivamente en las piezas que se presentan, quedando fuera del discurso las creencias, ideas, prácticas u otro tipo de valores que conforman el patrimonio cultural intangible, como vamos a ver en estos ejemplos.

La sección etnográfica del Museo de Cáceres ha sido una referencia hasta finales de los años ochenta del siglo pasado, cuando la obsolescencia de su museografía, no tanto de su discurso, terminó dando paso a otros modelos más recientes. La sección se articula en seis salas que ocupan la planta superior de la Casa de las Veletas y se dedican a la producción y transformación de recursos (agricultura y ganadería, pastoreo, caza, pesca, elaboración de queso y vino), organización económica, oficios, organización social, indumentaria, equipamiento doméstico, creencias y música.

Si hubiera que destacar alguna nota común en la Sección de Etnografía del museo cacereño deberíamos referirnos a la ausencia de presentaciones multimedia y el protagonismo de un discurso estrechamente ceñido a las colecciones, las cuales además muestran un cierto desequilibrio hacia la materia textil. Se trata de una presentación originada en la museografía de 1976, que tenía un criterio fundamentalmente taxonómico basado en los materiales expuestos y que ha ido evolucionando hacia un discurso más antropológico sustentado sobre todo en los textos explicativos y en una modesta reordenación de los contenidos de cinco de las seis salas.

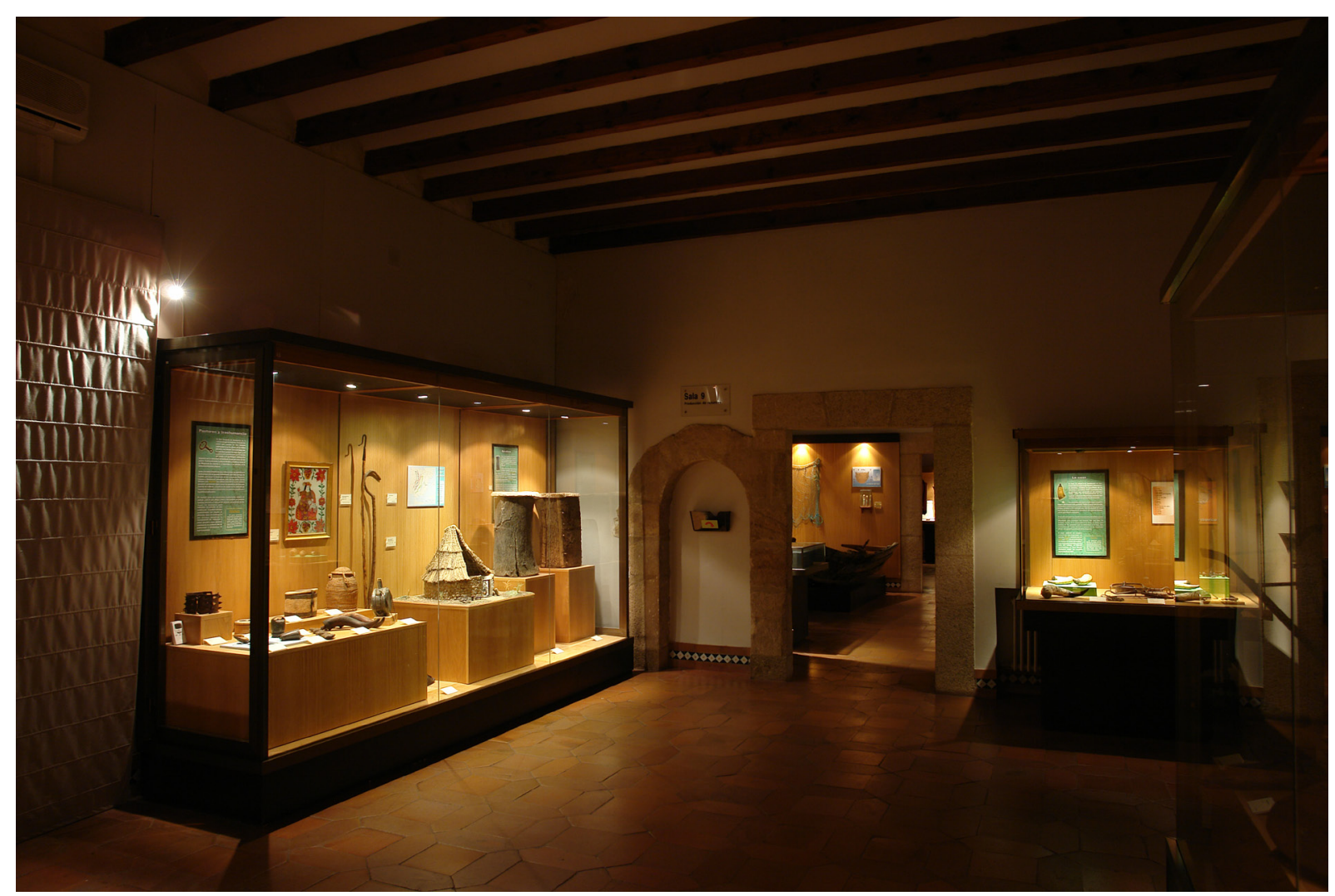

Foto 5. Sección de Etnografía del Museo de Cáceres (2008) (Archivo fotográfico del Museo de Cáceres) 
El segundo gran modelo de museo etnográfico de la región es sin duda el Museo Etnográfico Extremeño González Santana de Olivenza, que se articula en dos grandes apartados, la Sección de Etnografía y la de "otros", que incluye salas de Arqueología y Arte Sacro. En cuanto a la sección etnográfica, se presenta repartida en diecinueve espacios temáticos de dimensiones muy variables, a través de los que discurre la visita: utillaje agrícola y ganadero, cerámica popular, tienda de ultramarinos, bodega, almazara, herrería y forja, zapatería, carpintería sastrería, barbería, música, telar, casa popular labriega, bordados, casa burguesa, juguetes, consulta médica, imprenta e indumentaria. La exposición responde a una estructura diseñada en los primeros tiempos del museo (Vicente, 1995) que ha ido creciendo progresivamente a medida que se han incorporado nuevos espacios, pero en la que el modelo siempre repite la recreación de espacios, talleres, comercios o viviendas, con una gran acumulación de piezas que se ocupa muy poco de la explicación textual, de la introducción del patrimonio intangible o del uso de medios audiovisuales. Las salas de Arqueología y Arte aparecen como añadidos al museo sin ninguna articulación con el resto de las colecciones salvo el hecho de referirse a la misma localidad.

El Museo Etnográfico Pérez Enciso de Plasencia ocupa tres plantas del antiguo hospital de la ciudad, con una entrada en la que se expone una selección de objetos de técnicas y materias variadas, madera, barro, metales, junto a fotografías antiguas de Valentín Javier que tratan de ofrecer un contexto cultural de los objetos seleccionados. En la primera planta, la sala 1 acoge objetos que presentan el proceso de confección de tejidos de lino y lana a partir de las materias primas y la sala 2 muestra diferentes modelos del traje tradicional de la provincia cacereña; en la planta superior la sala 3 está dedicada al ajuar casero de lino, con una riquísima colección de bordados y encajes y de loza de Manises y de Talavera, mientras la sala 4 presenta una colección de "textil erudito" encarnada en piezas litúrgicas con especial mención al pontifical de Fernando VI. En este caso las piezas son presentadas en el interior de vitrinas salvo algún caso como la presentación de la cama de vistas, mientras que el traje tradicional se muestra sobre maniquíes y la información es sensiblemente más rica que en Olivenza, aun cuando sea ciertamente somera.

$\mathrm{Al}$ igual que el de Olivenza, el Museo Etnográfico de Don Benito ha "prescindido de vitrinas que tanta frialdad dan a las exposiciones, pero su utilización es inevitable cuando la conservación de las piezas lo exige" (Cidoncha, 2008: 19), es decir, para la indumentaria y las esculturas del conocido artista local Pedro Torre Isunza (1892-1982). Las salas se reparten por la antigua casa-palacio de los condes de Orellana ocupando más de cuarenta estancias expositivas; en la planta baja se ubican un antiguo despacho, la colección de Torre Isunza, indumentaria, consultas médicas, ultramarinos, juguetes, zapatería, caballitos de 
cartón, sastrería, escuela, cocina labriega, barbería, portal matancero, vivienda burguesa, capilla, sacristía, droguería, imprenta, bodega y cochera, y en la planta superior estudio fotográfico, cámaras agrarias, música, utillaje agrícola y ganadero, pesca y oficios varios. Encontramos de nuevo la acumulación de objetos "en su contexto" de los que se supone que el visitante sabe lo suficiente como para recibir más información, pero no existe hilo conductor ni entramado cultural en la visita, que se reduce a la presentación de una extraordinaria colección, cuantitativa y cualitativamente hablando.

Este mismo modelo de museo generalista en lo etnográfico lo vamos a encontrar reducido y adaptado a edificios y colecciones más modestas en numerosas localidades de la región, al igual que sucede en otras comunidades españolas. A título de ejemplo, nos referiremos al Museo Etnográfico "El Silo” de Garrovillas de Alconétar, inaugurado el 11 de agosto de 2012 y que en estos momentos ultima unas obras de ampliación. En él, nos encontramos con la museografía de ambientes ya conocida en el chozo de pastores y las salas de pesca, pastoreo, la matanza, zapatería, herrería, carpintería, cestería, vivienda labriega, ultramarinos, horno tejero, barbería, escuela, etc. con ausencia de cualquier tipo de explicación textual ni audiovisual.

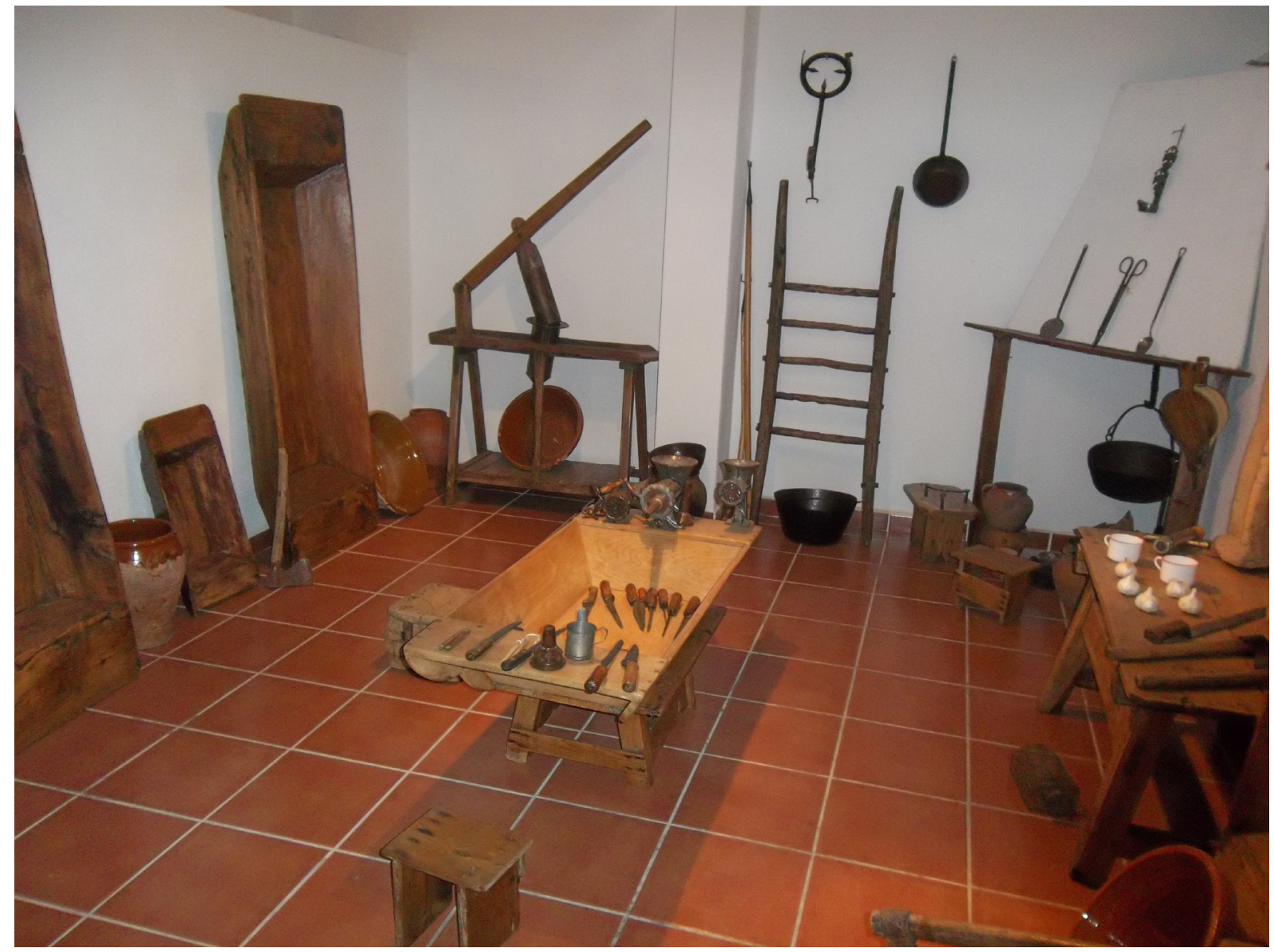

Foto 6. Museo Etnográfico "El Silo" de Garrovillas de Alconétar 
La parquedad o ausencia de datos explicativos en una parte significativa de este tipo de museos etnográficos responde por lo general a la creencia de que estos objetos y sus ambientes no requieren tales explicaciones, por ser ampliamente conocidos o recordados. Pero esto no es cierto, o cada vez lo es menos con los visitantes jóvenes, cuyo extrañamiento con respecto a estos objetos y al mundo rural que aspiran a representar es creciente, y para ellos una colmena de corcho es tan arqueológica e inexplicable como una cerámica cardial; así, la identidad local de la que tratan de revestirse estos museos se convierte en alteridad no sólo para el visitante foráneo, sino también para el autóctono perteneciente a generaciones que no han conocido la vigencia de los objetos que conforman ese patrimonio (Pais, 2008: 66).

\section{EL MUSEO ETNOGRÁFICO “DE PROCESO”}

En el marco de esa corriente renovadora que supuso la creación de los pequeños centros monográficos locales impulsado por la Red de Museos de Extremadura durante la pasada década, se trató de poner el énfasis en la presentación de procesos culturales, sociales y económicos peculiares o distintivos de las localidades o comarcas que los acogen, superando de ese modo el anterior discurso generalista de presentación de la "sociedad tradicional" para centrarse en los rasgos identificativos propios de la comunidad frente a las de su entorno. Dado que ya nos hemos referido de manera genérica a los diferentes proyectos que se pusieron en marcha, centraremos la exposición en tres ejemplos que sirven para caracterizar a estas nuevas instituciones: el Museo de la Alfarería de Salvatierra de los Barros, el Museo del Aceite de Monterrubio de la Serena y el Museo de la Cereza de Cabezuela del Valle.

En Salvatierra de los Barros, villa alfarera por excelencia de la provincia de Badajoz, el Museo de la Alfarería fue inaugurado en su primera fase en 2001, y dos años después en su configuración actual. En su planteamiento huye explícitamente del formato ya conocido de museo etnográfico para explicar la elaboración de cacharros de barro en su contexto histórico e importancia económica, tipología y uso, evolución formal y las respuestas de este sector esencial en la vida de Salvatierra a los retos de futuro planteados por la crisis de la cerámica tradicional (Calero y Carmona, 2009: 87-88). Para ello, el centro se estructura en dos áreas fundamentales, por un lado la introducción a que el visitante puede acceder en el llamado "centro de interpretación" que contextualiza la población y señala la importancia de la distribución nacional e internacional de las piezas de Salvatierra, para pasar a continuación a explicar, sobre todo a partir de imágenes, el proceso de fabricación de los cacharros desde la extracción del barro y su acarreo 
hasta el horneado y acabado. A esta primera aproximación le sigue un área de transición de contenido más arqueológico donde se presentan piezas de los siglos XVI y XVII y se explican diferentes técnicas decorativas que caracterizan la alfarería extremeña en su contexto fronterizo y las semejanzas observables con la misma artesanía en el lado portugués de la Raya. La segunda zona importante del museo se destina a la presentación del amplio repertorio de piezas fabricado en el pasado y en el presente por los alfareros de Salvatierra; para huir de la típica presentación tipológica, el proyecto museológico concibe esta área como la reconstrucción de una vivienda rural en la que las piezas cerámicas, aportadas en su gran mayoría por los artesanos, se insertan en el contexto de su uso (zaguán, cocina-comedor, bodega, dormitorio, corral, juguetes y construcción)

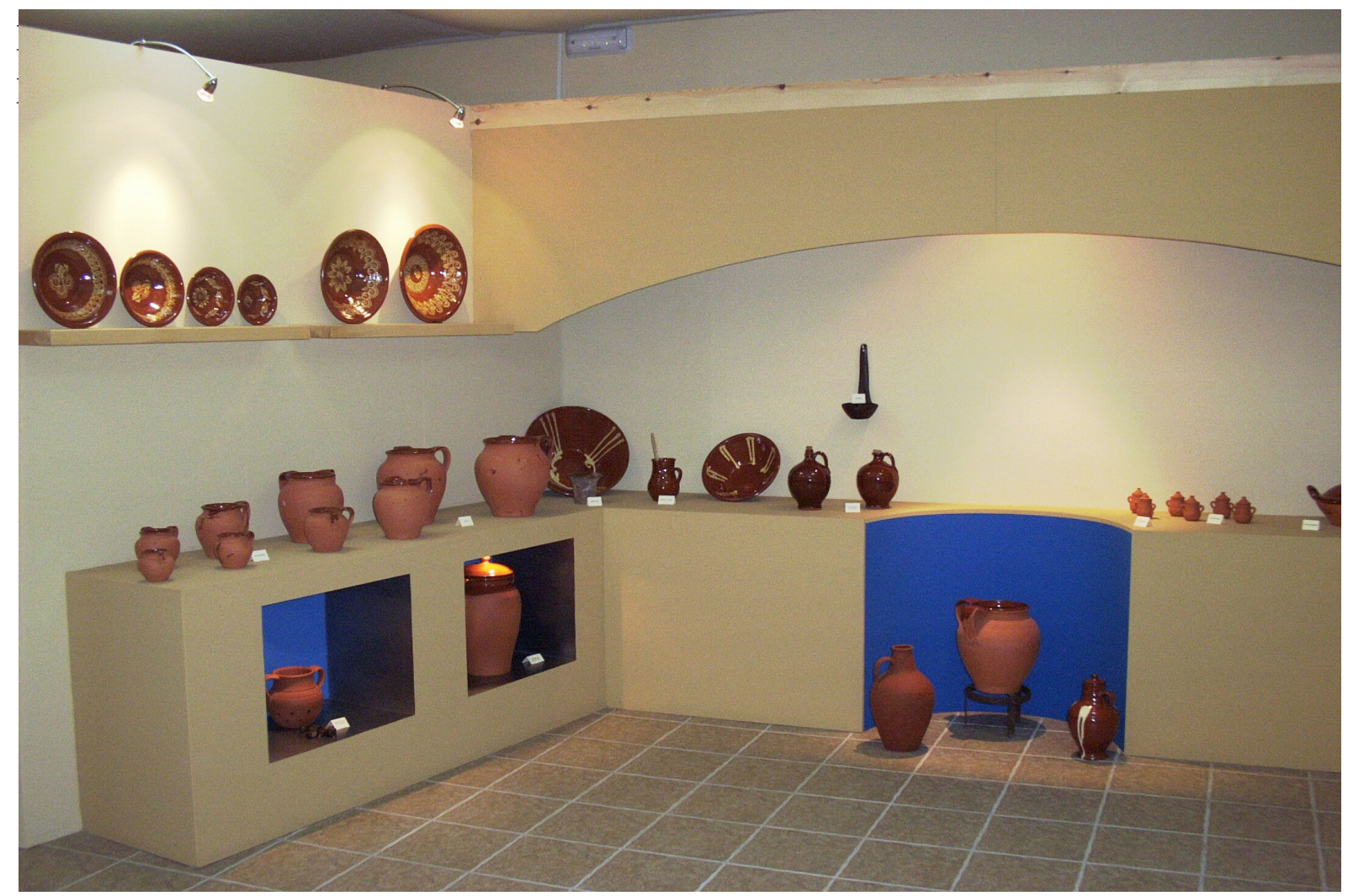

Foto 7. Museo de la Alfarería de Salvatierra de los Barros (Archivo fotográfico del M.A.S.)

La visita finaliza con la presentación de las creaciones más actuales de los alfareros de la localidad, que subrayan unas nuevas tendencias funcionales y artísticas con las que los artesanos se adaptan al cambiante mercado actual y futuro.

En su montaje, el Museo de Salvatierra no destierra por completo la vitrina, pero su uso queda restringido sólo para los objetos de mayor antigüedad; el mayor protagonismo lo adquiere la información visual y textual, sobre todo en la primera parte, y una recreación 
de ambientes muy estudiada que huye de la escenografía abigarrada, ya vista en otros casos, en que los espacios quedan solamente abocetados.

Monterrubio de la Serena es la localidad que da nombre a la Denominación de Origen de aceite de oliva del este de la provincia de Badajoz; durante el último medio siglo la producción olivarera se ha convertido en un verdadero monocultivo sobre todo en el propio Monterrubio, pero también en algunas de las dieciséis poblaciones del área protegida, las cuales se integran sobre todo en la comarca de la Serena, pero también en la Siberia y Campiña Sur. En este caso, estaba claro que el museo de nueva creación debía centrarse en el cultivo del olivar y en la elaboración y comercialización del aceite, pero debido a la reciente especialización de la comarca en este producto, el proyecto del nuevo museo debió comenzar su andadura partiendo desde cero y prácticamente sin colecciones (Jiménez, 2008: 132); la Red de Museos, en este caso, diseñó un programa de recogida de piezas con el apoyo de la Universidad Popular y de la Asociación de Pensionistas que en pocos meses permitió reunir los bienes culturales materiales necesarios para dar forma al proyecto.

El resultado final del Museo del Aceite, que como hemos avanzado se encuentra "temporalmente cerrado" cuando redactamos estas líneas, responde al modelo de "museo de identidad" a que nos venimos refiriendo, pero de alguna manera sigue respondiendo al museo etnográfico local de tipo generalista a causa de su procedimiento de creación. En efecto, la llamada a los vecinos para la donación o cesión de piezas destinadas a un museo del aceite ocasionó, como no podía ser de otro modo, que la respuesta incluyera aperos, enseres, objetos y documentos de todo tipo relativos a muy diferentes facetas de la vida social y los procesos productivos de la localidad. Por ello, la exposición permanente del centro debió conformarse en dos grandes áreas que se corresponden con las dos plantas principales del edificio de nueva construcción; la planta baja, por la que acceden los visitantes, incluye una introducción histórica sobre el cultivo del olivar y la elaboración y usos del aceite en el Mediterráneo desde la Antigüedad, ilustrada con piezas arqueológicas depositadas por el Consorcio de la Ciudad Monumental de Mérida, y otros dos bloques que abordan el inicio del cultivo a gran escala del aceite en la comarca, desde los años cincuenta del siglo pasado, y el surgimiento de las almazaras y los usos del olivar, con la evolución tecnológica reciente en los procesos de recolecta y molturación. En otro espacio de la misma planta, un video muestra el actual proceso de elaboración del aceite con los últimos avances tecnológicos que se van incorporando, y una muestra del producto final sirve para dar a conocer la Denominación de Origen protegida. 
Continuando la visita en la planta inferior, a la que se accede por una gran escalera que domina y condiciona todo el edificio, el visitante se encuentra con una presentación más próxima al modelo de museo etnográfico local, en la que se ha estructurado parte de los materiales donados o cedidos por los vecinos en varias áreas temáticas: el ciclo vital, el trabajo agrícola, medidas tradicionales y documentos personales y administrativos, todo ello en vitrinas de diferentes tipos y tamaños, que conviven con un video en el que se agrupan cientos de fotografías extraídas de los álbumes familiares de los habitantes de Monterrubio y con una muestra de aperos agrícolas que dibujan una solución de compromiso entre los dos conceptos de museo a que nos venimos refiriendo.

El tercer caso que escogemos es el Museo de la Cereza en Cabezuela del Valle, el corazón del Valle del Jerte conocido internacionalmente por la calidad y cantidad de su producción de cereza. Este monocultivo, que en realidad tiene poco más de un siglo de vigencia en el valle (Flores, 1992), marca en la actualidad la vida de toda la comarca, tal como trata de mostrar el museo inaugurado en 2007, que se concibe "como elemento de recuperación del patrimonio natural y tecnológico de nuestra comunidad" en el que las piezas expuestas "son los eslabones que unen cada fase del proceso presentado, articulando y fundamentando el mensaje y los recursos comunicativos empleados en el Museo" (Caldera y Tercero, 2005: 134-135).

El museo se aloja en una típica vivienda tradicional del valle, que ha sido reformada en su interior para adaptarla a su nueva finalidad; como en la mayor parte de estos museos de proceso, la planta baja acoge al visitante con un video explicativo sobre la historia, la evolución y los tipos de cultivo de la cereza. En la primera planta, mediante el uso de paneles explicativos y medios interactivos, el usuario puede conocer información básica sobre el árbol del cerezo, sus variedades y cultivo así como las enfermedades que le afectan y los medios para combatirlas, mientras que la segunda muestra la historia del cultivo en el valle y el proceso de producción y transformación de la cereza. En este proyecto el protagonismo pertenece a la información textual o visual en diferentes soportes, quedando los objetos reducidos a un número mínimo y siempre presentados de forma muy cercana al visitante, como si se tratara de elementos que en cualquier momento pueden ser retirados de la exposición para ser utilizados en la cerecera. Al mismo tiempo, las ventanas del edificio permiten un contacto visual directo con los bancales que rodean a la población, de los que se enseñorea el árbol del cerezo. 


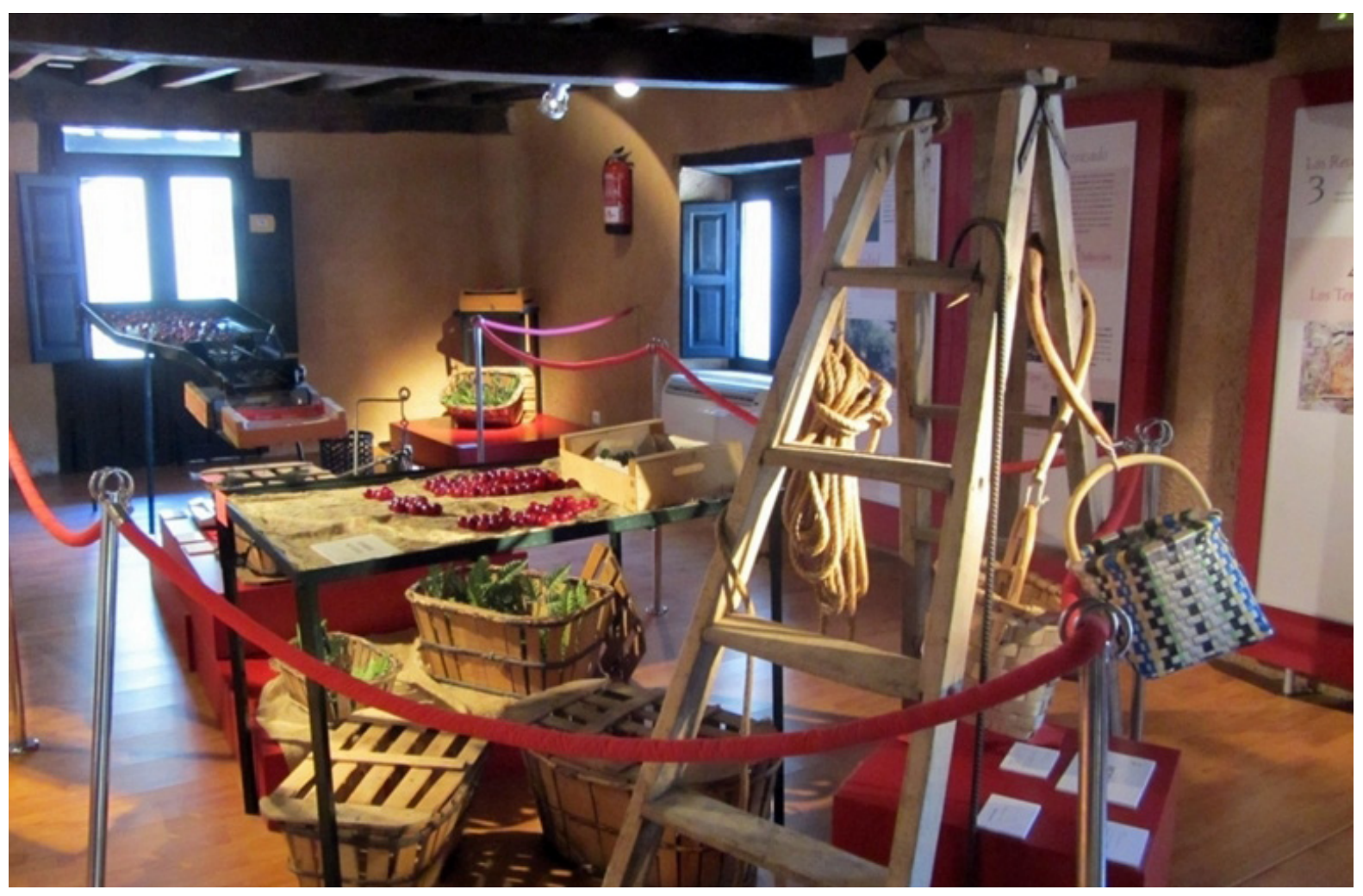

Foto 8. Museo de la Cereza de Cabezuela del Valle (Archivo fotográfico del Museo de la Cereza)

\section{CONCLUSIONES}

A grandes rasgos puede decirse, pues, que no hay un proyecto de presentación de la cultura regional en los museos extremeños, salvo que consideremos como tal los modelos etnográficos parciales que se observan en cuanto al ámbito geográfico y temático que presentan. El MEIAC (Museo Extremeño e Iberoamericano de Arte Contemporáneo), único centro no etnográfico que lleva el apellido "extremeño" en su denominación, también renuncia de facto a referir la cultura extremeña en tanto tiene un horizonte más amplio que abre sus salas a Portugal e Iberoamérica y en cuanto funciona más como centro de arte que como museo, con una exigua exposición permanente.

En cuanto a los ejemplos descritos, tanto los museos tradicionales como los más novedosos, en demasiados casos se acercan mucho a la presentación acrítica de una sociedad tradicional congelada en el tiempo cuya visión es casi idílica; cuando esto no es así y encontramos referencias a las adaptaciones ecológicas y culturales presentes y futuras, el patrimonio inmaterial gana terreno en los museos, aunque en determinadas ocasiones el papel de la institución como parte de un proceso general de vertebración del territorio se ve comprometido por un marcado protagonismo de lo local y por la progresiva debilidad de los lazos establecidos entre la comunidad y su museo una vez que éste va acumulando años en su funcionamiento y aquélla comprueba que sus 
elevadas expectativas de atracción turística y de negocio no llegan a cumplirse. Frente al modelo de museo de patrimonio glocal, basado en el discurso de la relación histórica entre lo local y lo global (Pereiro, 2009:171), la mayoría de los ejemplos extremeños se posicionan en el contexto de la globalidad mediante la afirmación de lo local en tanto búsqueda de la propia identidad.

En efecto, el creciente extrañamiento entre las comunidades locales y los museos que en gran medida se crearon de espaldas a ellas, o cuando menos sin darles participación en la gestión, compromete el futuro de unos centros que siguen dependiendo del sustento, cada vez más magro, de la administración regional. Tal situación pone de manifiesto la ausencia de tres elementos básicos necesarios para la creación y sostenimiento de un museo: una profunda reflexión previa sobre la necesidad de su creación, la garantía de su sostenibilidad y el entendimiento con la comunidad local que facilite decisiones consensuadas y compartidas en su creación y funcionamiento (Chagas, 2009-2010: 9394). A primera vista, los tiempos actuales no son los más adecuados para plantearse la necesaria reestructuración de esta realidad, pero como sostienen Zubiaur y Barrio (2014: 11), uno de los escasos efectos benéficos de la crisis es que ha sacado, de golpe, a los museos de su ensimismamiento, y les ha hecho comprender que a su papel como contenedor patrimonial, guardián de la memoria colectiva y destino turístico deben añadir el de armonizador social; de ahí que el papel activo de la sociedad en el devenir de los museos extremeños sea cada vez más necesario, y que los profesionales que deben estar al frente de ellos tienen la obligación de fomentar esa participación en la medida que las rígidas estructuras administrativas se lo permitan. 


\section{BIBLIOGRAFÍA}

Anderson, Ruth Matilda (1951) Spanish costume. Extremadura. New York: Hispanic Society of New York.

Antero de Zugasti, Julián (1862) Intereses materiales. Causas del retraso de Extremadura $y$ mejoras que deben introducirse. Madrid: Imprenta de D. Ramón Campuzano.

Barrientos Alfageme, Gonzalo (1990) Geografía de Extremadura. Badajoz: Universitas Editorial.

Beltrán Lloris, Miguel (2008) “Aquellos felices años de Cáceres, la ilusión del Museo”. En En delicada forma. 75 años del Museo de Cáceres en la Casa de las Veletas. Cáceres: Museo de Cáceres, pp. 85-94.

Caldera de Castro, María del Pilar y Tercero Iglesias, Segundo (2005) "Museos de identidad. Nuevos centros locales y comarcales en la Museografía Extremeña”. Revista de Museología 32, pp. 128-136.

Caldera de Castro, María del Pilar y Tercero Iglesias, Segundo (2008) "Los museos más allá de las coyunturas: Red de Museos de Extremadura”. En José Luis Alonso, Joaquín Díaz y Carlos Piñel (dirs.) (2008) Teoría y praxis de la museografía etnográfica. Zamora: Consejería de Cultura de la Junta de Castilla y León, pp. 31-39.

Calero Carretero, José Ángel y Carmona Barrero, Juan Diego (2009) "El museo de alfarería de Salvatierra de los Barros: un factor de recuperación de la artesanía del barro extremeño-alentejana”. Revista de Estudios Extremeños LXV (I), pp. 75-100.

Calvo Buezas, Tomás (1996) “La identidad extremeña. Hacia la nueva imagen”. En Florencio Vicente, Antonio Ventura Díaz, María Isabel Fajardo y María Isabel Ruiz (eds.) Identidad y fronteras culturales: Antropología y Museística. Badajoz: Asociación de Psicología Extremadura, pp. 53-70.

Caro Baroja, Julio (1976) [1946] Los Pueblos de España. Madrid: Istmo.

Chagas, Mario (2009-2010) "Los museos en el marco de la crisis". Museos.es 5-6, pp. 86101.

Cidoncha Martín de Prado, Rosa (2008) Museo Etnográfico de Don Benito. Don Benito: Excmo. Ayuntamiento.

Cordero, Juan Luis (1917) Regionalismo. Problemas de la provincia de Cáceres. Barcelona: Tipografía Maucci.

Delgado Méndez, Aniceto (2012) Antropología, territorio y Patrimonio: los museos etnográficos en Extremadura. Badajoz: Consejería de Educación y Cultura. 
Flores del Manzano, Fernando (1988) "El problema de la identidad de Extremadura". Alcántara 13-14, pp. 33-43.

Flores del Manzano, Fernando (1992) La vida tradicional en el Valle del Jerte. Mérida: Asamblea de Extremadura.

González Mena, María Ángeles (1976) Museo de Cáceres. Sección de Etnografía. Madrid: Ministerio de Educación y Ciencia.

González Mena, María Ángeles (1986) Muestra Etnográfica Cacereña. Artes y costumbres populares. Cáceres: Institución Cultural El Brocense-Diputación Provincial.

Hervás, Marciano de (2014) "La judería de Hervás (Cáceres): historia de una invención". En XLII Coloquios Históricos de Extremadura. Trujillo: Asociación Cultural Coloquios Históricos de Extremadura, pp. 255-283.

Jiménez Villalba, Félix (2008) "La mirada interdisciplinar en un museo de proceso. Museo del Aceite de Monterrubio de la Serena". En Centro para la participación y el Desarrollo Humano Sostenible CEPAD (ed.) Cultura y Patrimonio. Compartiendo experiencias entre Chiquitos y Extremadura. Santa Cruz de la Sierra, Bolivia: Centro para la participación y el Desarrollo Humano Sostenible, pp. 131-136.

http://www.cepad.org/index.php?option=com remository\&Itemid=13\&func=startdow n\&id=61 [Acceso el 20 de marzo de 2015]

Limpo Píriz, Luis A. (2005) "Museo Etnográfico Extremeño González Santana de Olivenza”. Revista de Museología 32, pp. 103-108.

Marcos Arévalo, Javier (1992) "Bases para la creación del Museo Etnológico de la Comunidad Autónoma de Extremadura”. Anales del Museo del Pueblo Español IV, pp. 117-144.

Marcos Arévalo, Javier (1995a) La construcción de la Antropología Social extremeña (Cronistas, interrogatorios, viajeros, regionalistas y etnógrafos). Cáceres: Universidad de Extremadura.

Marcos Arévalo, Javier (1995b) "Los museos etnográficos en Extremadura". Anales del Museo Nacional de Antropología 2, pp. 165-190.

Marcos Arévalo, Javier (1998) "La identidad extremeña. Reflexiones desde la Antropología social”. Gazeta de Antropología 14.

http://www.ugr.es/ pwlac/G14 04Javier Marcos Arevalo.html [Acceso el 28 de enero de 2015].

Martín Nájera, Aurora (2005) "La génesis de un museo: de colección particular a Museo Etnográfico Textil Pérez Enciso de Plasencia”. Revista de Museología 32, pp. 83-91. 
Naredo, José Manuel (1978) “Una síntesis del expolio extremeño”. En Mario Gaviria, José Manuel Naredo y Juan Serna (coords.) Extremadura saqueada. Recursos naturales y autonomía regional. París: Ruedo Ibérico, pp. 105-107.

Pais de Brito, Joaquim (2008) "Museos y colecciones etnográficas. Objetos y atribución de sentido”. En José Luís Alonso, Joaquín Díaz y Carlos Piñel (dirs.) Teoría y praxis de la museografía etnográfica. Zamora: Consejería de Cultura de la Junta de Castilla y León, pp. 65-72.

Palacios Martín, Bonifacio (1988) "Origen de la conciencia regional extremeña: el nombre y el concepto de Extremadura”. Alcántara 13-14, pp. 9-22.

Pereiro Pérez, Xerardo (2009) Turismo cultural. Uma visão antropológica. Colección Pasos Edita 2. Tenerife: Asociacion Canaria de Antropología.

http://www.pasosonline.org/Publicados/pasosoedita/PSEdita2.pdf [Acceso el 17 de marzo de 2015]

Sánchez Gómez, Luis Ángel (2013) "La reencarnación de lo efímero o cuando las exposiciones universales parían museos". Revista de Dialectología y Tradiciones Populares LXVIII (1), pp. 145-166.

Sánchez González, Juan (1997) “José López Prudencio. Ideal e identidad de Extremadura”. Cuadernos Populares 56. Mérida: Editora Regional de Extremadura.

Sánchez Marroyo, Fernando (1998) "Antonio Elviro Berdeguer. De la lucha regionalista al compromiso por el socialismo". Cuadernos Populares 57. Mérida: Editora Regional de Extremadura.

Valadés Sierra, Juan M. (2008) "La época de Miguel Ángel Orti Belmonte como director del Museo de Cáceres (1921-1951)”. En En delicada forma. 75 años del Museo de Cáceres en la Casa de las Veletas. Cáceres: Museo de Cáceres, pp. 21-40.

Valadés Sierra, Juan M. (2010) "Museos locales y museos provinciales en Extremadura. Una mirada crítica”. Revista de Estudios Extremeños LXVI (III), pp. 1067-1126.

Valadés Sierra, Juan M. (2010a) "El Museo, de albacea de la memoria a producto turístico". En Javier Marcos Arévalo y Rosanna E. Ledesma (eds.) Bienes culturales, turismo $y$ desarrollo sostenible. Sevilla: Signatura Demos, pp. 161-194.

Valadés Sierra, Juan M. (2013) "La aportación cacereña al Pabellón de Extremadura en la Exposición Ibero-Americana de Sevilla (1929)”. Revista de Estudios Extremeños LXIX (III), pp. 1811-1880.

Vicente Castro, Florencio (1995) Museo Etnográfico Extremeño González Santana. Olivenza. Mérida: Editora Regional de Extremadura. 
VV. AA. (1988) Extremadura como problema. Revista Alcántara 13-14.

Zubiaur Carreño, Francisco Javier y Barrio Fernández, Teresa (2014) "Crisis y museos. Una oportunidad para hacer las cosas mejor”. Revista de Museología 61, pp. 7-12. 